\title{
Fate of bacterial production in a heterotrophic ecosystem: grazing by protists and metazoans in the Hudson Estuary
}

\author{
Dolors Vaqué ${ }^{1}$, Michael L. Pace ${ }^{2, *}$, Stuart Findlay ${ }^{2}$, David Lints ${ }^{2}$ \\ ${ }^{1}$ Institut de Ciències del Mar, Pg. Nacional s/n, E-08039 Barcelona, Spain \\ ${ }^{2}$ Institute of Ecosystem Studies, New York Botanical Gardens, Box AB, Millbrook, New York 12545-0129, USA
}

\begin{abstract}
The Hudson River Estuary is a heterotrophic ecosystem with high rates of planktonic bacterial production. We measured grazing on bacteria in monthly experiments during 1990 to determine: (1) the primary consumers of bacteria; (2) whether absolute rates of grazing on bacteria were high relative to other systems; and (3) whether bacteria were a sufficient carbon resource for consumers. Fluorescent minicells were used to measure the ingestion of bacteria by heterotrophic flagellates and ciliates. Using the abundances of bacteria, rotifers and cladocerans in the river, we also estimated zooplankton clearance rates. Total grazing of the plankton community was assessed by measuring the disappearance of fluorescent minicells over 24 and $48 \mathrm{~h}$. Heterotrophic flagellates were the primary consumers of bacteria with ciliates and the cladoceran Bosmina longirostris also important seasonally. Ingestion of bacteria by heterotrophic flagellates, ciliates, and $B$. longirostris was sufficient at most times to satisfy estimated carbon requirements of these consumers. Large bacterial size and relatively low consumer populations in the Hudson account for the apparent sufficiency of bacteria as a carbon source. We conclude that grazing on bacteria in the Hudson River is similar to the levels of grazing observed in other systems. Nevertheless, bacteria are a potentially significant resource, because the dominant planktonic consumers are capable of ingesting bacteria at rates sufficient to support carbon demands.
\end{abstract}

\section{INTRODUCTION}

Depending on food web structure, bacteria may be either a link in food webs supporting metazoan production or largely a sink where bacterial production is respired by microorganisms (e.g. Ducklow et al. 1986, Pomeroy \& Deibel 1986, Pace et al. 1990, Wylie \& Currie 1991). Most investigations of bacteria in aquatic food webs have been carried out on the plankton of lakes and marine systems where bacterial production is typically $30 \%$ of primary production on an areal basis (reviewed by Cole et al. 1988). Many nearshore marine and estuarine systems, however, are heterotrophic in the sense that total system respiration exceeds primary production (Smith 1991). In these systems allochthonous organic matter may be an espe-

\footnotetext{
- Addressee for correspondence
}

cially significant carbon source supporting bacterial production (Coffin \& Sharp 1987, Painchaud \& Therriault 1989). Under these circumstances, bacteria might be a particularly significant resource for higher consumers presuming bacteria can grow on alloch thonous carbon.

An example of such a strongly heterotrophic ecosystem is the Hudson River Estuary. Bacteria and phytoplankton are only weakly coupled in this system, and bacterial production exceeds primary production by 2 - to 3 -fold (Findlay et al. 1991). Total system respiration estimates are consistent with the measurements of bacterial production and the notion that respiration is far in excess of phytoplankton primary production (Howarth et al. 1992). The Hudson River Estuary, with relatively high rates of bacterial production and low rates of primary production, represents an interesting contrast to other systems in which the significance of bacteria in food webs has been investigated. 
In this study we address 3 general questions about the utilization of bacterial production in the Hudson River Estuary. First, what organisms are the main consumers of bacteria? In addition to protists, potential consumers are rotifers and cladocerans in the pelagic portion of the system (Pace et al. 1992). Second, are the high rates of bacterial production in the Hudson River Estuary coupled with comparatively high rates of grazing? Our goal here is not to determine whether grazing balances production, as we have previously argued that methods of measuring bacterial processes are probably not yet sufficient to make such evaluations (Pace et al. 1990). Rather, our purpose is to determine whether grazing rates are relatively high in a system with high bacterial production compared to systems with lower production. In a system with high grazing, consumers would remove a larger percentage of the bacterial standing stock per day relative to a system with low grazing. A third question is, are bacteria a carbon source capable of supporting some or all of these consumer populations? Here, we address the issue of whether consumption of bacteria is potentially sufficient to support total carbon demand of bacterial grazers in the Hudson ecosystem.

\section{MATERIALS AND METHODS}

Sampling and enumeration of bacteria, flagellates, ciliates, rotifers and cladocerans. This study was conducted in the tidal portion of the Hudson River at a station near Kingston, New York, USA, located $158 \mathrm{~km}$ north of New York City. Characteristics of this station have been described previously (Findlay et al. 1991). The river is ca $1 \mathrm{~km}$ wide at this station. Samples were collected from a boat approximately $300 \mathrm{~m}$ from the shore. Sampling was conducted every $2 \mathrm{wk}$ at $0.5 \mathrm{~m}$ depth from April to November 1990 with a peristaltic pump to determine heterotrophic bacterial abundance and production as well as the abundance of flagellates, ciliates, rotifers and cladocerans

The abundances of bacteria, heterotrophic flagellates, and ciliates were determined by epifluorescence microscopy. We did not take replicate samples in the field so we have no estimate of the sampling error Below, we present the analytical error of each method. For bacteria we used the acridine orange direct count method (Hobbie et al. 1977). Duplicate bacterial preparations were made with 10 random fields counted on each filter. The coefficient of variation $(\mathrm{CV}=$ standard deviation $\div$ mean) across fields averaged $13 \%$ (range 6 to $25 \%$ ). Heterotrophic flagellates were stained with proflavin (Haas 1982), preserved with glutaraldehyde (1\% final solution) and immediately filtered on $1 \mu \mathrm{m}$ Nuclepore filters prior to counting. Some flagellates pass through $1 \mu \mathrm{m}$ filters (Wikner \& Hagström 1988) so that our counts underestimate the actual abundance Random $10 \mathrm{~mm}$ strips (90 $\mu \mathrm{m}$ width) were counted on each filter. The average $\mathrm{CV}$ across strips including both filters was $11 \%$ (range: 4 to $26 \%$ ). Ciliates were stained with 4,6-diamidino-2-phenylindole (DAPI) and preserved with glutaraldehyde ( $2 \%$ final solution) Subsamples of 10 to $20 \mathrm{ml}$ were filtered on a $5 \mu \mathrm{m}$ Nuclepore filter. In order to count sufficient ciliates, a single large area of $84 \mathrm{~mm}^{2}$ on each filter was surveyed at $1250 \times$ magnification by repeated transects and the number of ciliates recorded. Ciliate counts were not replicated because of the considerable time required to make a single count. Triplicate samples of rotifers and cladocerans were taken at each sampling time. Rotifers were concentrated by passing 2 l of water through a $35 \mu \mathrm{m}$ sieve. These samples were preserved in a sucrose-formalin solution and subsequently counted with an inverted microscope at $100 \times$ magnification. Cladocerans were sampled with a pump described by Pace (1986). Samples were preserved in a sucrose-formalin solution and enumerated with a stereomicroscope at $25 \times$ magnification.

Measurement of production and grazing. Bacterial production was measured with the $\left[{ }^{3} \mathrm{H}\right]$ thymidine method following the protocol of Findlay et al. (1984, 1991). Four $10 \mathrm{ml}$ subsamples were amended with $40 \mu \mathrm{Ci}$ of $\left[{ }^{3} \mathrm{H}\right.$ ] thymidine (specific activity: $80 \mathrm{Ci} \mathrm{mmol}^{-1}$ ) and incubated for $30 \mathrm{~min}$ at in situ temperature. Incubations were ended by adding $2 \mathrm{mI}$ of $5 \%$ formaldehyde. Time zero controls were used to correct for non-biological uptake of the label by adding $5 \%$ formaldehyde to two $10 \mathrm{ml}$ subsamples immediately after label addition. After incubation, bacteria were collected on $0.2 \mu \mathrm{m}$ polycarbonate filters. Filters including the edges were washed with ice cold $5 \%$ trichloroacetic acid. Filters were frozen and subsequently extracted for DNA using acid-base hydrolysis (see Findlay et al. 1991). Radioactivity associated with the DNA fraction was determined using liquid scintillation counting. The $\mathrm{CV}$ for the replicate $10 \mathrm{ml}$ subsamples averaged $20 \%$ (range: $<1$ to $42 \%$ ). Bacterial production was calculated using the average isotope dilution measured in a previous study $(10.1 \mathrm{nmol}$ sample $e^{-1}$ ) and using a conversion factor of $1 \times 10^{9}$ cells produced $\mathrm{nmol}^{-1}$ of thymidine incorporated into DNA (Findlay et al. 1991).

Measurements of grazing by flagellates on bacteria were carried out at approximately monthly intervals from May to October 1990. Ciliate grazing was also measured on 4 occasions (July to October). Triplicate 1 I water samples were taken from the surface water $(0.5 \mathrm{~m})$ and maintained at in situ temperature. Feeding by heterotrophic flagellates and ciliates was measured using a fluorescent minicell technique (Pace et al. 
1990) modified from the method of Wikner et al. (1986). A minicell producing strain of Escherichia coli was cultured in liquid medium, and minicells separated using sucrose gradient centrifugation. Minicells are spheri$\mathrm{cal}$ and ca $0.5 \mu \mathrm{m}$ in diameter (volume $=0.065 \mathrm{\mu m}^{3}$ ). Minicell size is similar to the average bacteria in the Hudson River (ca $0.58 \mu \mathrm{m}$ diameter or $0.1 \mu \mathrm{m}^{3}$ volume; see Findlay et al. 1991). Minicells were stained with 5 (4,6-dichlorotriazin-2-yl)-aminofluorescein (DTAF) following the protocol of Sherr et al. (1987). Prior to use in experiments, minicells were sonicated to aid dispersal.

Minicells were added to each replicate 1 l sample at approximately $10 \%$ of bacterial concentration. Subsamples for protists were taken immediately and at several times within $1 \mathrm{~h}$ : 0, 15, 30, and $60 \mathrm{~min}$ for flagellates, and 0 and 15 min for ciliates. The length of the incubation was set to avoid egestion and still obtain sufficient minicells within food vacuoles for counting (McManus \& Okubo 1991). Subsamples were preserved with an equal volume of ice-cold $4 \%$ glutaraldehyde (Sanders et al. 1989). Minicells and bacteria in the subsamples were counted using epifluorescence microscopy. Flagellates and ciliates were stained with DAPI, filtered on $1 \mu \mathrm{m}$ Nuclepore filters, and frozen. Random transects of each filter were counted at $1250 \times$ until approximately 100 flagellates, and 20 to 50 ciliates were enumerated. The number of minicells within each flagellate and ciliate was recorded.

For each replicate we determined the abundances of minicells, bacteria, flagellates and ciliates. Ingestion rates (bacteria protist ${ }^{-1} \mathrm{~d}^{-1}$ ) were calculated by multiplying the number of minicells ingested by the ratio of bacteria to added minicells (see Pace et al. 1990). Community grazing rates (bacteria $\mathrm{l}^{-1} \mathrm{~d}^{-1}$ ) were calculated by multiplying ingestion rates per protist by abundance.

An alternative approach to these short-term measures of grazing is to measure the disappearance of minicells in longer-term incubations. These experiments allow one to estimate total grazing on bacteria but do not provide information on which consumers are responsible for the ingestion of bacteria. The experiments have the advantage of being much less labor intensive so that it is possible to perform more replicate measures improving the precision of grazing estimates. On each occasion when short-term grazing rates were measured, we also measured the disappearance of minicells at 24 and $48 \mathrm{~h}$. Minicells were added to $1 \mathrm{l}$ polycarbonate bottles at approximately $10 \%$ of the in situ bacterial concentration. A total of 9 bottles were used in each experiment with 2 serving as killed controls (poisoned with a $1 \%$ final solution of formaldehyde). Subsamples of minicells were taken from each bottle at the beginning and end of the experiment to determine initial and final concen- trations respectively. The DTAF-labeled minicells were counted in a manner similar to bacteria using epifluorescence microscopy.

In order to estimate whether bacteria would be a sufficient carbon source for flagellates and ciliates we needed to estimate the carbon content of cells based on average size. To determine size, we measured the lengths and widths of protists. Volumes were estimated by assuming cells approximated spheres in the case of flagellates. For ciliates, we considered only the 2 dominant groups assuming choreotrichs approximated spheres and scuticociliates approximated ellipsoids. Carbon content was estimated using literature conversion factors as follows: flagellates, $0.22{\mathrm{pg} \mu \mathrm{m}^{-3}}^{-3}$ (Børsheim \& Bratbak 1987); ciliates, $0.15 \mathrm{pg} \mu^{-3}$ (DeBiase et al. 1990). For bacteria in the Hudson, we have previously estimated a carbon content of $0.028 \mathrm{pg}$ C cell ${ }^{-1}$ (Findlay et al. 1991).

Estimation of grazing by rotifers and cladocerans. We compared our measurements of grazing by protists to potential grazing rates by rotifers and cladocerans. In the Hudson River the dominant cladoceran is Bosmina longirostris (Pace et al. 1992). We assumed a clearance rate of $1 \mu \mathrm{l}$ ind.$^{-1} \mathrm{~h}^{-1}$ for rotifers (Bogdan \& Gilbert 1982). For B. longirostris, we measured the clearance rate on a single occasion. Animals were collected from the river, concentrated in the laboratory, and 50 individuals sorted into $60 \mathrm{ml}$ BOD bottles. Radiolabeled minicells were added to a final concentration $5.6 \times 10^{6} \mathrm{ml}^{-1}$ (see Pace et al. 1990 for method). Bottles were placed in a dark incubator, at in situ temparature, and the animals allowed to feed for $60 \mathrm{~min}$. Animals were concentrated on a $35 \mu \mathrm{m}$ net, quickly killed by dipping the net into boiling water, and then rinsed briefly on a GF/F filter with distilled water. The filter was then digested with tissue solubilizer and assayed for radioactivity. Blanks for these measurements were $B$. longirostris killed immediately prior to the experiment with carbonated water and otherwise treated in the same manner as the experimental samples.

\section{RESULTS}

\section{Seasonal patterns of heterotrophic bacteria, flagellates, ciliates and zooplankton}

Bacteria ranged from $1.9 \times 10^{9}$ to $7.6 \times 10^{9}$ bacteria $1^{-1}$, and heterotrophic flagellates from $0.9 \times 10^{6}$ to $1.7 \times 10^{6}$ flagellates $1^{-1}$. Bacteria were more variable $(\mathrm{CV}=38 \%)$ than flagellates (CV $=24 \%)$ across the sampling period (Fig. 1a). Typically, flagellates are more variable than bacteria in field studies (Wright et al. 1987, Vaqué \& Pace 1992) conforming with expectations from predator-prey models (Wright 1988). The 

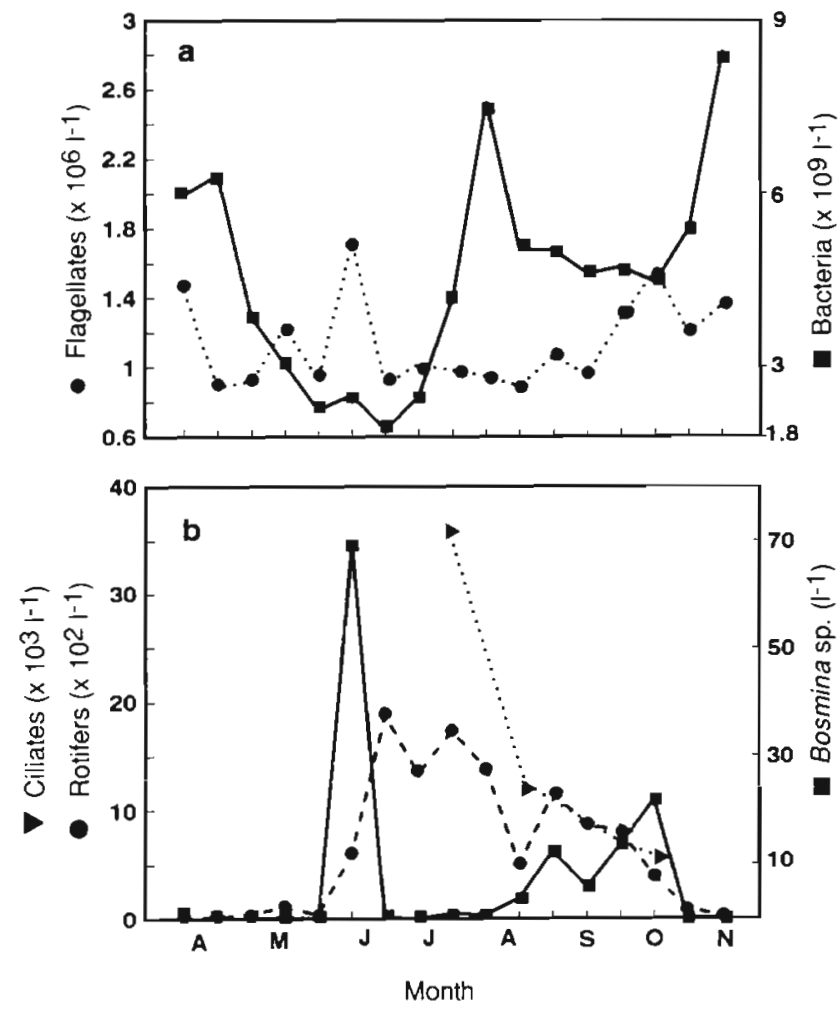

Fig. 1 Abundance of (a) bacteria and heterotrophic flagellates and (b) ciliates, rotifers and Bosmina longirostris in the Hudson River during 1990

lower variability of flagellates in the Hudson may suggest regulation of this group by factors other than food resources. Ciliate abundances were only determined from July through October. Maximum densities of $3.5 \times 10^{4} \mathrm{l}^{-1}$ were observed in July with lower and similar values (ca $1 \times 10^{4} \mathrm{l}^{-1}$ ) for the other 3 mo (Fig. 1b). The dominant taxa were scuticociliates and choreotrichs. Rotifer abundances ranged from 12 to 1900 ind $1^{-1}$. Highest densities were observed in the middle of the summer (Fig. 1b). The sampling error for rotifers expressed as the CV averaged $20 \%$ (range 7 to $50 \%$ ). The dominant rotifers were species of Polyarthra, Keratella, and Trichocerca. Bosmina Iongirostris was the primary cladoceran as other species were never present at abundances $>1$ ind. $1^{-1}$. Two peaks in abundance were observed, one in June of approximately 69 ind. $1^{-1}$ and the other in October of 22 ind. $1^{-1}$ (Fig. 1b). CV's for B. longirostris samples were often high averaging $43 \%$ (range 2 to $100 \%$ ).

\section{Grazing on bacteria by protists and zooplankton}

Rates of grazing on bacteria were relatively low for the first 3 experiments conducted in early and late May and in June. Rates were considerably higher from July through October (Fig. 2). Overall, protists were more important than zooplankton as consumers of bacteria, although at certain times zooplankton abundances were sufficiently high that these organisms may also have been significant consumers (Fig. 2).

Heterotrophic flagellates were always the most important group in terms of grazing with maximum rates of $5.9 \times 10^{8}$ bacteria $\mathrm{I}^{-1} \mathrm{~d}^{-1}$ in July (Fig. 2). Most of the flagellates were small free-living forms, and generally over $70 \%$ were in the size class of $1-3 \mu \mathrm{m}$ in diameter Ciliates were also significant grazers. We observed many scuticociliates (mostly 15 to $20 \mu \mathrm{m}$ maximum diameter), and these forms were the primary consumers of bacteria among the ciliates.

Rotifer densities were sufficiently high in June, July, August and September that if our estimated grazing rate is reasonable, bacterial consumption might have been as great as $1.7 \times 10^{8}$ bacteria $1^{-1} \mathrm{~d}^{-1}$ (Fig. 2). Our estimates for rotifers, however, are highly uncertain. We appiied a single rate to the entire community which consisted mainly of Keratella sp., Polyarthra sp., and Trichocerca sp. Keratella sp. might be capable of ingesting small planktonic bacteria, but this is not clearly established for Polyarthra sp. (Bogdan et al. 1980, Bogdan \& Gilbert 1982). The other common rotifer, Trichocerca sp., probably does not graze bacteria at all. Our estimates for Bosmina longirostris are more certain. We made a single laboratory estimate with a mean ( $\pm 1 \mathrm{SD}$ ) of $10.4 \pm 1.4 \mu \mathrm{l}$ ind.$^{-1} \mathrm{~h}^{-1}$. This may be an underestimate since the feeding time was long relative to the gut passage time (Peters 1984), but we found the longer feeding period necessary to obtain sufficient labeling of the

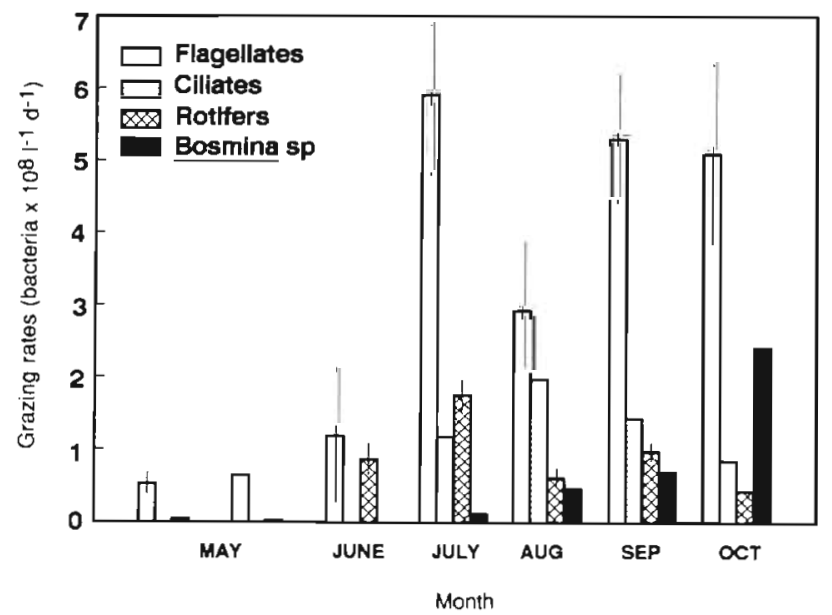

Fig. 2. Grazing on bacteria by heterotrophic flagellates, ciliates (July to October, no replicates), rotifers and Bosmina longirostris in the Hudson River during 1990. Error bars = $1 \mathrm{SD}, \mathrm{n}=3$. When not visible, either mean values were too small or $\mathrm{SD}<5 \%$ of the mean. For flagellates, SD's were determined from triplicates. For rotifers and B. longirostris, SD's are based on triplicate estimates of abundance and a fixed estimate of feeding rate 
animals. Nevertheless, this rate is in excellent agreement with the average rate we derived from the literature of $10 \mu \mathrm{l}$ ind.$^{-1} \mathrm{~h}^{-1}$ (Pedrós-Alió \& Brock 1983, Porter et al. 1983, Børsheim \& Andersen 1987). We used a clearance rate of $10 \mu \mathrm{l}$ ind.$^{-1} \mathrm{~h}^{-1}$ in all our calculations. Grazing by $B$. longirostris was only significant in October. We estimated zooplankton grazing on bacteria only for the times when we also conducted direct experiments to measure grazing by protists. Experiments were not conducted during the early season peak of $B$. longirostris (Fig. 1b), and it is likely that during this time $B$. longirostris was also an important consumer of bacteria.

\section{Total grazing as estimated in minicell disappearance} experiments

In the long-term experiments minicell abundance in poisoned controls did not change significantly over $48 \mathrm{~h}$ while minicells in the experimental containers declined (Fig. 3a). In the July experiment when loss rates were highest, minicells declined linearly for $48 \mathrm{~h}$ and over $50 \%$ were removed (Fig. 3a).

Bacterial loss rates calculated from minicell disappearances were always $>0$ except in the initial experiment (begining of May) where no decline was observed for the first 24 h (data not shown). Rates were
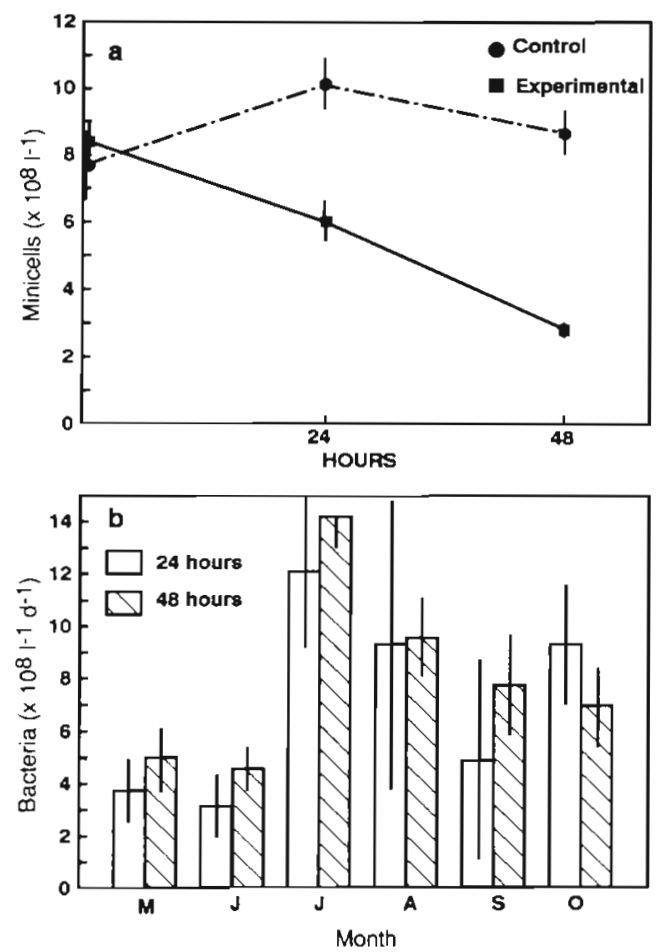

Fig. 3. (a) Disappearance of minicells in the July experiment and (b) removal rates of bacteria estimated from the 24 and $48 \mathrm{~h}$ incubations. Error bars $=1 \mathrm{SD}$ higher if measured over $48 \mathrm{~h}$ in all but the October experiment (Fig. 3b). These differences, however, were not significant ( $t$-test, $p>0.05$ ) except for the October experiment $(p=0.04)$ where the 24 h rate was higher than the $48 \mathrm{~h}$ rate. It is likely that the higher rates of bacterial loss over $48 \mathrm{~h}$ in most experiments were due to some growth of bacterial feeding protists in the containers; however, we did not count protists in any of these experiments to test this idea. One advantage of the longer incubations was increased precision (Fig. 3b). The average CV for the $48 \mathrm{~h}$ measurements was $19 \%$ whereas the average $\mathrm{CV}$ for the $24 \mathrm{~h}$ measurements was $44 \%$. The increased precision was possible because a greater loss of minicells was measured over $48 \mathrm{~h}$ so that the differences calculated for each replicate were less affected by analytical error in the minicell counts (similar to the error for bacterial counts, see (Methods'). We use the 48 h estimates in subsequent comparisons below, but the conclusions we derive are independent of this choice.

\section{Comparison of bacterial abundance and production with grazing}

As we have observed previously (Findlay et al. 1991), rates of bacterial production and the turnover times of bacteria in the Hudson River are very high. Average production at the time of these experiments was $2.7 \times 10^{9}$ bacteria $\mathrm{l}^{-1} \mathrm{~d}^{-1}$, and the average turnover time was $1.4 \mathrm{~d}$. Bacterial standing stock and productivity were moderately high during early May and were lowest during the subsequent 2 sampling times. From July on, bacterial abundance exceeded $4 \times$ $10^{9}$ cells $1^{-1}$ and production rose to high values in September and October (Fig. 4). Loss rates observed in

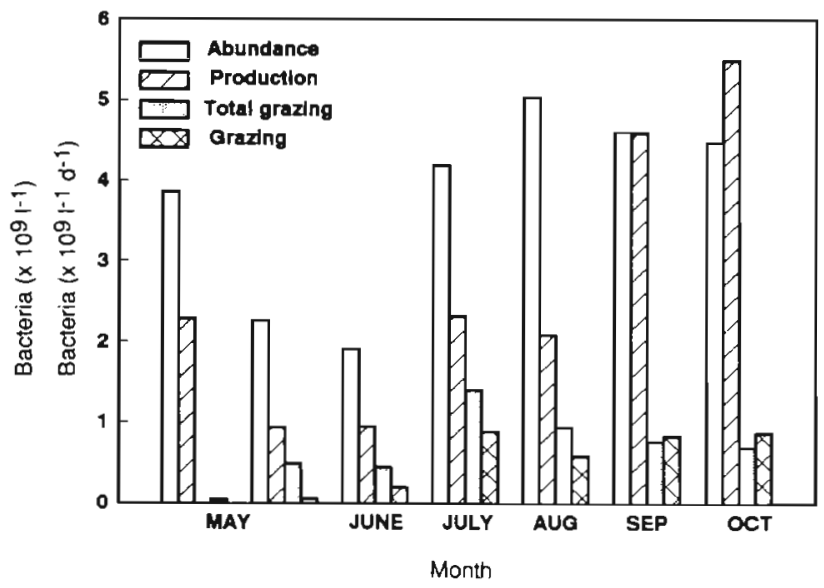

Fig. 4. Abundance, production, disappearance of minicells over $48 \mathrm{~h}$, and grazing (sum of grazing by flagellates, ciliates. rotifers, and Bosmina longirostris) 
the long-term experiments ranged from $4.5 \times 10^{8}$ to $14 \times 10^{8}$ cells $\mathrm{l}^{-1} \mathrm{~d}^{-1}$ (maximum in July). Our more direct estimates of grazing fell in a similar, but slightly lower range $\left(0.6 \times 10^{8}\right.$ to $8.9 \times 10^{8}$ cells $\left.\mathrm{I}^{-1} \mathrm{~d}^{-1}\right)$. In general, the 2 methods of measuring grazing compared favorably and gave approximately the same values (Fig, 4). In 4 of the 6 experiments, direct estimates of grazing were 63 to $125 \%$ of the rate measured with the minicell disappearance method. In the late May and June experiments agreement was poor with the direct measures of grazing being 14 and $46 \%$ of the minicell disappearance rate respectively. In all cases, estimates of production were substantially greater than either measure of grazing (minicell disappearance or grazing as equal to the sum of consumption by all taxa; Fig. 4).

\section{Bacteria as a carbon source for consumers}

Although the number of bacteria that predators remove per day in the Hudson River was not particularly high (only a small percentage of bacterial standing stock 3 to $21 \%$ ), we can estimate whether consumption of bacteria was sufficient to supply the carbon requirements of the various types of grazers. We consider the case of flagellates, ciliates, and Bosmina longirostris, because for each of these groups we have direct estimates of grazing (as opposed to rotifers). For this purpose we need to either measure or assume the size, carbon content, growth rate, and growth efficiency (production $\div$ ingestion) of the respective consumers to arrive at the carbon required in terms of ingestion. Direct measurements of the flagellates (average volume $=16 \mu^{3}$ ) and ciliates (average for choreotrichs plus scuticociliates, volume

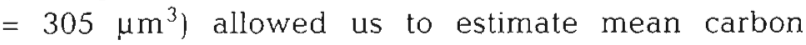
content using literature conversion factors (see 'Methods'). We assume a growth efficiency of $30 \%$ for flagellates and ciliates. Growth efficiencies determined by several authors range widely from 2 to $82 \%$, but $30 \%$ is within the range of commonly reported values (Caron \& Goldman 1990). For B. longirostris the average individual is about $0.2 \mathrm{~mm}$ long with a dry weight of $0.43 \mu \mathrm{g}$ ('Methods' in Pace et al. 1992). Assuming a carbon to dry weight ratio of $45 \%$ (Andersen \& Hessen 1991), the carbon content is $0.195 \mu \mathrm{g} \mathrm{C}$. Metazoan zooplankton growth efficiencies often fall in the range of 10 to $40 \%$ (Omori \& Ikeda 1984). We assume an efficiency of $20 \%$ for $B$. longirostris. We further assume relatively rapid rates of growth for protists of $1 \mathrm{~d}^{-1}$ and for Bosmina $\mathrm{sp}$. of $0.2 \mathrm{~d}^{-1}$. A final step is to convert the consumer demand in carbon units to number of bacteria (see 'Methods') in order to compare with measured inges- tion rates. Given these estimates and assumptions, flagellates, ciliates and $B$. longirostris require 17.5 , 227 and $2.90 \times 10^{5}$ bacteria ind. ${ }^{-1} \mathrm{~h}^{-1}$ respectively.

These carbon requirements can be compared to our actual measures of ingestion rate (Fig. 5). Flagellate carbon requirements exceed bacterial ingestion rates early in the season but from July to October ingestion rates can account for 50 to $100 \%$ of estimated requirements (Fig. 5a). Since the assumed growth requirements are relatively high, it is likely that bacteria alone are a sufficient resource for July through October. The difference between early and late season in terms of whether bacteria are a sufficient carbon resource is related primarily to differences in flagellate ingestion. Flagellate abundances were similar throughout the season while ingestion rates per flagellate were very low in May and June (1 to 3 bacteria flagellate ${ }^{-1} \mathrm{~h}^{-1}$ ) compared to July through October (10 to 18 bacteria flagellate $\mathrm{h}^{-1}$ ). Ciliates and Bosmina Iongirostris typically ingested enough bacteria throughout the study to support their assumed carbon requirements (Fig. 5b, c).

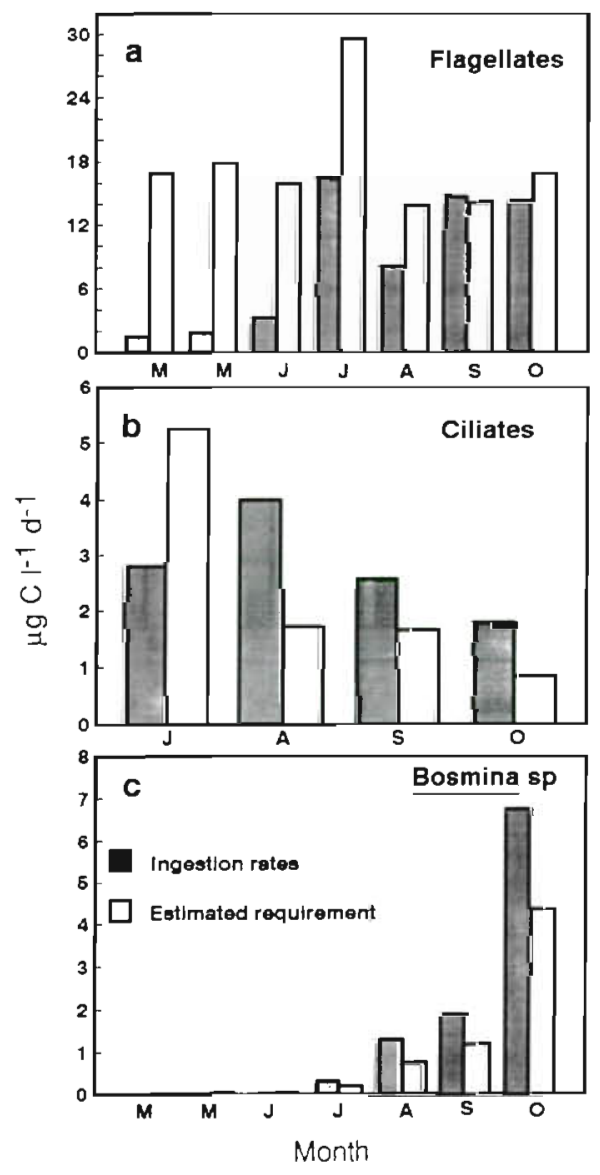

Fig. 5. Ingestion rates and estimated carbon requirements of (a) heterotrophic flagellates, (b) ciliates and (c) Bosmina longirostris in the Hudson River 


\section{DISCUSSION}

Heterotrophic flagellates were the main grazers of bacteria in the Hudson River Estuary as is the case in many lakes (Sanders et al. 1989, Weisse \& Müller 1990) and other marine systems (Cof fin \& Sharp 1987, Rosenberg et al. 1990). Ciliates are also significant bacterial consumers in the Hudson as has been described for turbid salt marsh creeks and adjacent waters by Sherr et al. (1989a, b). In the Hudson the primary ciliates consuming bacteria were scuticociliates which had high per cell ingestion rates relative to other forms. Choreotrichs usually dominate planktonic communities (Carlough \& Meyer 1989, Sanders et al. 1989, Sherr et al. 1989b). These forms are present, but not dominant in the Hudson. While many choreotrichs ingest bacteria (Sherr et al. 1989b), some do not as has been demonstrated in other studies (Sanders et al. 1989, Pace et al. 1990). Cladocerans consume bacteria generally with a lower efficiency than larger particles, but when cladocerans are abundant they can be important bacterial grazers (Pace et al. 1990). This is the case in the Hudson. When Bosmina longirostris is abundant (typically 2 population maxima each year; see Pace et al. 1992), grazing by this species is similar in magnitude to grazing by protists

Overall, grazing on bacteria in the Hudson River is not particularly high even given high bacterial production rates. Grazing rates per individual consumer are typical of values found in previous field studies. For example, in other studies using fluorescent particles mean ingestion rates of heterotrophic flagellates ranged from a low of 3.2 (Simek et al. 1990) to as high as 25 bacteria :lagellate ${ }^{-1} \mathrm{~h}^{-1}$ (Pace et al. 1990). These rates overlap with the average we found in the Hudson River $\left(\right.$ mean $=8.5$; range 1 to 19 bacteria flagellate ${ }^{-1}$ $\mathrm{h}^{-1}$ ). Similarly for ciliates, mean rates from prior field studies using fluorescent bacteria range from 101 (Sherr et al. 1989a) to 683 bacteria ciliate ${ }^{-1} \mathrm{~h}^{-1}$ (Carlough \& Meyer 1990). In the Hudson we observed an average rate of 357 bacteria ciliate ${ }^{-1} \mathrm{~h}^{-1}$ and a range of 118 to 506 bacteria ciliate ${ }^{-1} \mathrm{~h}^{-1}$.

Another way to evaluate whether grazing rates are high in the Hudson relative to other systems is to compare the percent of bacterial standing stock removed per day (Table 1). In systems with high grazing, we would expect a larger percentage removal than in systems with low grazing. Note that this argument is independent of the amount of production consumed by grazers, because even in the most oligotrophic ecosystem where the total number of bacteria consumed may be very low such consumption may represent $100 \%$ of the productivity. We do not find strong evidence that bacteria are heavily grazed, and thereby, a proportionately more significant constituent in the food web relative to more widely studied lentic systems (i.e.
Table 1. Comparison of the percentage of bacterial standing stock grazed per day (bacte:ia grazed $\div$ bacterial abundance) in the Hudson River and other aquatic systems in the USA. Measurements of 'uptake' quantify ingestion using fluorescently labeled particle techniques over shorter time periods (min to $1 \mathrm{~h}$ ) while 'disappearance' quantifies the removal of particles over longer time periods ( 1 to $2 \mathrm{~d}$ )

\begin{tabular}{|c|c|c|c|}
\hline $\begin{array}{l}\text { System } \\
\text { (Date) }\end{array}$ & $\begin{array}{c}\text { Uptake } \\
\text { (Range) } \\
\% \mathrm{~d}^{-1}\end{array}$ & $\begin{array}{c}\text { Disappearance } \\
\text { (Range) } \\
\% \mathrm{~d}^{-1}\end{array}$ & Source \\
\hline $\begin{array}{l}\text { Hudson R., NY } \\
\text { (May-Oct) }\end{array}$ & $\begin{array}{c}10.1 \\
(3-16)\end{array}$ & $\begin{array}{c}20.4 \\
(15-34)\end{array}$ & This study \\
\hline $\begin{array}{l}\text { Paul L., MI } \\
\text { (May-Aug) }\end{array}$ & $\begin{array}{c}3.2 \\
(2-5)\end{array}$ & - & $\begin{array}{l}\text { Vaqué \& } \\
\text { Pace (1992) }\end{array}$ \\
\hline $\begin{array}{l}\text { Tuesday L., MI } \\
\text { (May-Aug) }\end{array}$ & $\begin{array}{c}3.4 \\
(1-22)\end{array}$ & - & $\begin{array}{l}\text { Vaqué \& } \\
\text { Pace (1992) }\end{array}$ \\
\hline $\begin{array}{l}\text { Upton L., NY } \\
\text { (Apr-Oct) }\end{array}$ & $\begin{array}{c}20.5 \\
(8-67)\end{array}$ & $\begin{array}{c}17.1 \\
(11-40)\end{array}$ & $\begin{array}{l}\text { Pace et al. } \\
(1990)\end{array}$ \\
\hline $\begin{array}{l}\text { Oglethorpe L., NY } \\
\text { (Feb-Sep) }\end{array}$ & $\begin{array}{c}5.8 \\
(3-35)\end{array}$ & - & $\begin{array}{l}\text { Sanders et } \\
\text { al. (1989) }\end{array}$ \\
\hline $\begin{array}{l}\text { Woods Hole, MA } \\
\text { (Dec-Jul) }\end{array}$ & - & $\begin{array}{c}10.2 \\
(3-61)\end{array}$ & $\begin{array}{l}\text { Marrasé et } \\
\text { al. (unpubl.) }\end{array}$ \\
\hline $\begin{array}{l}\text { Ogeechee R., GA } \\
\text { (Apr-Sep) }\end{array}$ & $\begin{array}{c}3.3 \\
(1-100)\end{array}$ & - & $\begin{array}{l}\text { Carlough \& } \\
\text { Meyer (1991) }\end{array}$ \\
\hline
\end{tabular}

lakes, open water marine). For example, in the shortterm experiments the percentage of bacteria consumed by protists per day ranges from 3 to $16 \%$, and the percentage of bacteria removed in long term experiments (disappearance) ranged from 15 to $34 \%$ (Table 1 ). These values are comparable to percentages measured in lakes, a nearshore marine system, and a blackwater river using similar methods (Sanders et al. 1989, Pace et al. 1990, Carlough \& Meyer 1991, Vaqué \& Pace 1992, C. Marrasé, E. L. Lim \& D. A. Caron unpubl.). While the Hudson River is a strongly heterotrophic ecosystem with high absolute rates of bacterial production, we conclude that these higher rates of production are not matched by similarly high levels of grazing.

One potential problem with our work is that the thymidine-based production rates may not be accurate. Our method involves measuring the quantity of thymidine which is incorporated into DNA based on a chemical extraction technique (Findlay et al. 1991). We have previously evaluated this method in the Hudson and found that isotope dilution is signficant, and our estimates are corrected for this effect. Further, we can constrain the production estimates by independent measurements of respiration on unfiltered Hudson River water conducted at the same time as our thymidine assays (Findlay et al. 1992). These respiration measurements were done by continuous measurement of the decline in dissolved oxygen in sealed flasks with $\mathrm{O}_{2}$ electrodes and represent total community respiration. The percentage of bacterial production to total community respiration, both in units of $\mu \mathrm{g} \mathrm{C} \mathrm{l}^{-1} \mathrm{~d}^{-1}$, 
averaged $58 \%$ (range: 35 to $82 \%, n=7$ ). If bacterial production had exceeded or been more nearly equal to respiration, this would suggest we were overestimating bacterial production given the constraints that phytoplankton respiration must also be a component of the total and that bacterial growth efficiencies are unlikely to exceed $50 \%$. We have no basis for concluding the thymidine rates are overestimates. Alternatively, if we accept the thymidine-based production rates, we cannot identify the fate of bacteria except by suggesting that benthic consumers and viruses may be significant sources of mortality. Attempts to balance production and grazing rate estimates are hindered by methodological uncertainty and our incomplete knowledge of the sources of bacterial mortality (Pace 1988).

When we estimated the carbon requirements of the Hudson River bacterial grazers, we found that ingested bacterial carbon would be sufficient in many cases to meet carbon demand. There are several reasons why bacteria may be a sufficient resource. First, bacterial cells in the Hudson River, while similar in size to the minicells we used to estimate grazing, are fairly large when compared to bacteria from other systems. Cell volumes average about $0.1 \mu \mathrm{m}^{3}$ in the Hudson (Findlay et al. 1991) while in the aerobic waters of 17 lakes, cell volumes average about $0.02 \mu \mathrm{m}^{3}$ using similar methods (J. J. Cole, M. L. Pace, N. F. Caraco \& G. S. Steinhart unpubl.). Consumers, therefore, obtain more carbon per cell when ingesting bacteria in the Hudson. Second, while bacteria are large, consumers tended to be small and some occurred at relatively low abundances. For example, flagellates were typically 1 to $3 \mu \mathrm{m}$. These small cells have lower carbon requirements per capita. Further, flagellate abundances were typically $10^{6} \mathrm{l}^{-1}$. These densities are lower than found in many other systems with bacterial abundances similar to the Hudson (Berninger et al. 1991). Ciliates, while moderately abundant isee Carlough \& Meyer 1990 for comparisons), were also small. Bacterial ingestion rates were high for these consumers and nearly sufficient to support carbon requirements (Fig 4). Surprisingly, bacteria also appeared to be a sufficient resource for Bosmina longirostris. While B. longirostris may potentially meet carbon requirements by ingesting bacteria, other sources of carbon (e.g. phytoplankton) are also significant. Hence, we conclude that consumption of bacteria in the Hudson ecosystem is relatively low, but sufficient to maintain the actual populations of consumers.

The results of this study do not allow us to make a clear distinction between the food webs in autotrophic vs heterotrophic ecosystems. Bacteria are not utilized to a higher degree in the Hudson than they are in other lake, river and marine systems (Table 1). The most parsimonious hypothesis at this point is that pelagic food webs in these 2 types of ecosystems operate similarly despite the large differences in the ratio of bacterial to primary production. Further analysis is needed of the relative utilization of primary production and of the differences between benthic and pelagic processes in these 2 types of ecosystems. Making such comparisons remains an important challenge in order to establish to what extent differences in system metabolism and net biogeochemical fluxes drive, or are at least coupled with, distinct patterns of microbial production and the utilization of this production.

Acknowledgements. This research was supported by a grant from the Hudson River Foundation and a postdoctoral fellowship to D.V. from CSIC, Spain. We thank Marisol Felip for help in the lab and field. This paper is a contribution to the program of the Institute of Ecosystem Studies.

\section{LITERATURE CITED}

Andersen, T. Hessen, D. O. (1991). Carbon, nitrogen and phosphorus content of freshwater zooplankton. Limnol. Oceanogr. 36: 807-814

Berninger, U. G., Finlay, B. J., Kuuppo-Leinikki, P. (1991) Protozoan control on bacterial abundances in freshwater. Lirnnol. Oceanogr. 36: 139-147

Bogdan, K G., Gilbert, J. J., Starkweather, P. L. (1980). In situ clearance rates of planktonic rotifers. Hydrobiologia 73 $73-77$

Bogdan, K. G., Gilbert, J. J. (1982). Seasonal patterns of feeding by natural populations of Keratella, Polyarthra, and Bosmina: Clearance rates, selectivities, and contributions to community grazing. Limnol. Oceanogr. 27: 918-934

Borsheim, K. Y., Andersen, S. (1987). Grazing and food size selection by crustacean zooplankton compared to production of bacteria and phytoplankton in a shallow Norwegian mountain lake. J. Plankton Res. 9: 367-379

Børsheim, K. Y., Bratbak G. (1987). Cell volume to carbon conversion factors for a bacterivorous Monas sp. enriched from seawater. Mar. Ecol. Prog. Ser. 8: 211-223

Carlough, L. A., Meyer, J. L. (1989). Protozoans in two southeastern blackwater rivers and their importance to trophic transfer. Limnol. Oceanogr. 34: 163-177

Carlough, L. A., Meyer, J. L. (1990). Rates of protozoan bacterivory in three habitats of a southeastern blackwater river. J. N. Am. Benthol. Soc. 9: 45-53

Carlough, L. A., Meyer, J. L. (1991). Bacterivory by sestonic protists in a southeastern blackwater river. Limnol. Oceanogr. 36: 873-883

Caron, D. A., Goldman, J. C. (1990). Protozoan nutrient regeneration. In: Capriulo, G. M. (ed.) Ecology of marine protozoa. Oxford University Press, Oxford, p. 283-306

Coffin, R. B., Sharp, J. H. (1987). Microbial trophodynamics in the Delaware estuary. Mar. Ecol. Prog. Ser. 41: 253-266

Cole, J. J., Findlay, S., Pace, M. L. (1988). Bacterial production in fresh and saltwater ecosystems: a cross-system overview. Mar. Ecol. Prog. Ser. 43: 1-10

DeBiase, A. E., Sanders, R. W., Porter, K. G. (1990). Relative nutritional value of ciliate protozoa and algae as food for Daphnia. Microb. Ecol. 19: 199-210

Ducklow, H. W., Purdie, D. A., Williams, P. J. LeB., Davies, J. M. (1986). Bacterioplankton: a sink for carbon in a coastal marine plankton community. Science 232: 865-867 
Findlay, S. E. G., Meyer, J. L., Edwards, R. (1984). Measuring bacterial production via rate of incorporation of $\left[{ }^{3} \mathrm{H}\right]$ thymidine into DNA. J. Microbiol. Meth. 2: 57-72

Findlay, S. E. G., Pace, M. L., Lints, D., Cole, J. J., Caraco, N. F. Peierls, B. (1991). Weak coupling of bacterial and algal production in a heterotrophic ecosystem: the Hudson River estuary. Limnol. Oceanogr. 36: 268-278

Findlay, S., Pace, M. L., Lints, D., Howe, K. (1992). Bacterial metabolism of organic carbon in the tidal freshwater Hudson Estuary. Mar. Ecol. Prog. Ser. 89: 147-153

Haas, L. (1982). Improved epifluorescence microscopy for observing planktonic micro-organisms. Ann. Inst. Oceanogr. Paris 58: 261-266

Hobbie, J. E., Daley, R. J., Jasper, S. (1977). Use of Nuclepore filters for counting bacteria by fluorescence microscopy. Appl. environ. Microbiol. 33: 1225-1228

Howarth, R. W., Marino, R., Garritt, R., Sherman, D. (1992). Ecosystem respiration and organic carbon processing in a large tidally influenced river: the Hudson River. Biogeochemistry 16: 83-102

McManus, G. B., Okubo, A. (1991). On the use of surrogate food particles to measure protistan ingestion. Limnol. Oceanogr. 36: 613-617

Omori, M., Ikeda, T. (1984). Methods in marine zooplankton ecology. John Wiley \& Sons, New York

Pace, M. L. (1986). An empirical analysis of zooplankton community size structure across lake trophic gradients. Limnol. Oceanogr. 3: 45-55

Pace, M. L. (1988). Bacterial mortality and the fate of bacterial production. Hydrobiologia 159: 41-49

Pace, M. L., McManus, G. B., Findlay, S. E. G. (1990). Planktonic community structure determines the fate of bacterial production in a temperate lake. Limnol. Oceanogr. 35: 795-808

Pace, M. L., Findlay, S. E. G., Lints, D. (1992). Zooplankton in advective environments: the Hudson river community and a comparative analysis. Can. J. Fish. Aquat. Sci. 49: $1060-1069$

Painchaud, J., Therriault, J. C. (1989). Relationship between bacteria, phytoplankton and particulate organic carbon in the upper St. Lawrence estuary. Mar. Ecol. Prog. Ser. 56: 301-311

Pedrós-Alió, C., Brock, T D. (1983). The impact of zooplankton feeding on the epilimnetic bacteria of a eutrophic lake. Freshwat. Biol. 13: 227-239

Peters, R. H. (1984). Methods for the study of feeding, grazing, and assimilation by zooplankton. In: Downing, J. A., Rigler, F. H. (eds.) A manual on methods for the assessment of secondary productivity in fresh waters. Blackwell Scientific Publications, Boston, p. 336-402

Pomeroy, L. R., Deibel, D. (1986). Temperature regulation of bacterial activity during the spring bloom in Newfoundland coastal waters. Science 233: 359-361

Porter, K. G., Feig, Y. S., Vetter, E. F. (1983). Morphology, flow regimes, and filtering rates of Daphnia, Ceriodaphnia, and Bosmina fed natural bacteria. Oecologia 58: 156-163

This article was presented by D. A. Caron, Woods Hole, Massachusetts, USA
Rosenberg, R., Dahl, E., Edler, L., Fyrberg, L., Graneli, E., Graneli, W., Hagström, Å., Lindahl, O., Matos, M. O., Pettersson, K., Sahlsten, E., Tiselius, P., Turk, V., Wikner. J (1990). Pelagic nutrients and energy transfer during spring in the open and coastal Skagerrak. Mar. Ecol. Prog. Ser. 61. 215-231

Sanders, R. W., Porter, K. G., Bennett, S. J., DeBiase, A. E. (1989). Seasonal patterns of bacterivory by flagellates, ciliates, rotifers, and cladocerans in a freshwater planktonic community. Limnol. Oceanogr. 34: 673-687

Sherr, B. F., Sherr, E. B., Fallon, R. D. (1987). Use of monodispersed fluorescently labeled bacteria to estimate in situ protozoa bacterivory. Appl. environ. Microbiol. 53: 958-965

Sherr, B. F., Sherr, E. B., Pedrós-Alió, C. (1989a). Simultaneous measurement of bacterioplankton production and protozoan bacterivory in estuarine water. Mar. Ecol. Prog. Ser. 54: $209-219$

Sherr, E. B., Rassoulzadegan, F., Sherr, B. F. (1989b). Bacterivory by pelagic choreotrichous ciliates in coastal waters of the NW Mediterranean Sea. Mar. Ecol. Prog. Ser. 55: $235-240$

Simek, K., Macek, M., Vynálek, V. (1990). Uptake of bacteriasized fluorescent particles by natural protozoan assemblage in a reservoir. Arch. Hydrobiol. Beih. Ergebn. Limnol. 34: 275-281

Smith, S. V. (1991). Stoichiometry of C:N:P fluxes in shallowwater marine ecosystems. In: Cole, J. J., Lovett, G. M., Findlay, S. E. G. (eds.) Comparative analyses of ecosystems: patterns, mechanisms, and theories. SpringerVerlag, New York, p. 259-286

Vaqué, D., Pace, M. L. (1992). Grazing on bacteria by flagellates and cladocerans in lakes of contrasting food web structure. J. Plankton Res. 14: 307-323

Weisse, T., Muller, H. (1990). Significance of heterotrophic nanoflagellates and ciliates in large lakes: evidence for Lake Constance. In: Tilzer, M. M., Serruya, C. (eds.) Large lakes: ecological structure and function. Springer-Verlag, Madison, p. 549-555

Wikner, J., Andersson, A., Normark S., Hagström, A. (1986). Use of genetically marked minicells as a probe in measurement of predation on bacteria in aquatic environments. Appl. environ. Microbiol. 52: 4-8

Wikner, J., Hagström, $\AA$. (1988). Evidence for a tightly coupled nanoplanktonic predator-prey link regulating the bacterivores in the marine environment. Mar. Ecol. Prog. Ser. 50: $137-145$

Wright, R. T., Coffin, R. B., Lebo, M. (1987). Dynamics of planktonic bacteria and heterotrophic microflagellates in the Parker Estuary, Northern Massachusetts. Cont. Shelf Sci. 7: 1383-1397

Wright, R. T. (1988). A model for short-term control of the bacterioplankton by substrate and grazing. Hydrobiologia 159: $111-117$

Wylie, J. L., Currie, D. J. (1991). The relative importance of bacteria and algae as food sources for crustacean zooplankton. Limnol. Oceanogr. 36: 708-729

Manuscript first received: January 27, 1992

Revised version accepted: October 20, 1992 